University of Wollongong

Research Online

$1-1-2017$

Board Gender Diversity and Corporate Response to Sustainability Initiatives: Evidence from the Carbon Disclosure Project

Walid Ben-Amar

University of Ottawa

Millicent M. Chang

University of Western Australia, mchang@uow.edu.au

Philip Mcllkenny

University of Ottawa

Follow this and additional works at: https://ro.uow.edu.au/buspapers

Part of the Business Commons

Research Online is the open access institutional repository for the University of Wollongong. For further information contact the UOW Library: research-pubs@uow.edu.au 


\title{
Board Gender Diversity and Corporate Response to Sustainability Initiatives: Evidence from the Carbon Disclosure Project
}

\author{
Abstract \\ This paper investigates the effect of female representation on the board of directors on corporate \\ response to stakeholders' demands for increased public reporting about climate change-related risks. We \\ rely on the Carbon Disclosure Project as a sustainability initiative supported by institutional investors. \\ Greenhouse gas emissions measurement and its disclosure to investors can be thought of as a first step \\ toward addressing climate change issues and reducing the firm's carbon footprint. Based on a sample of \\ publicly listed Canadian firms over the period 2008-2014, we find that the likelihood of voluntary climate \\ change disclosure increases with women percentage on boards. We also find evidence that supports \\ critical mass theory with regard to board gender diversity. These findings reinfo rce initiatives being \\ undertaken around the world to promote gender diversity in corporate governance while demonstrating \\ board effectiveness in stakeholder management.

\section{Disciplines \\ Business}

\section{Publication Details} \\ Ben-Amar, W., Chang, M. \& Mcllkenny, P. (2017). Board Gender Diversity and Corporate Response to \\ Sustainability Initiatives: Evidence from the Carbon Disclosure Project. Journal of Business Ethics, 142 \\ (2), 369-383.
}




\title{
Board Gender Diversity and Corporate Response to Sustainability Initiatives: Evidence from the Carbon Disclosure Project
}

\begin{abstract}
$\underline{\text { Abstract }}$
This paper investigates the effect of female representation on the board of directors on corporate response to stakeholders' demands for increased public reporting about climate change related risks. We rely on the Carbon Disclosure Project (CDP) as a sustainability initiative supported by institutional investors. Greenhouse Gas (GHG) emissions measurement and its disclosure to investors can be thought of as a first step towards addressing climate change issues and reducing the firm's carbon footprint.

Based on a sample of publicly listed Canadian firms over the period 2008-2014, we find that the likelihood of voluntary climate change disclosure increases with women percentage on boards. We also find evidence that supports critical mass theory with regard to board gender diversity. These findings reinforce initiatives being undertaken around the world to promote gender diversity in corporate governance while demonstrating board effectiveness in stakeholder management.
\end{abstract}

Keywords: Sustainability Disclosure, Climate change, Greenhouse Gas Emissions, Gender

Diversity, Corporate Governance, Board of Directors. 


\section{Introduction}

This paper investigates the relationship between female representation on boards and the voluntary disclosure of climate change information, two major social and environmental issues that are transforming the corporate competitive landscape. Morality and ethics are central to these two issues and the demand to integrate environmental and social considerations into corporate values is being driven by shareholders, customers, employees and other stakeholders.

The main issue we address is whether female representation on the board of directors impacts the firm's decision to voluntarily respond to major stakeholders' demands for increased public reporting about greenhouse gas $(\mathrm{GHG})$ emission levels and climate change related risks? Prior research has mainly focused on the gender diversity - financial performance relationship and much less is known about the channels through which female participation on the board affects firm performance. To better understand this relation, recent studies have explored the link between female directors and the adoption of corporate social responsibility (CSR) practices (Bear et al, 2010; Seto-Pamies, 2013; Zhang et al., 2013). Two recent studies directly related to ours are PradoLorenzo \& Garcia-Sanchez (2010) and Liao, Luo \& Tang (2014) where the particular emphasis was on the relation between gender diversity and GHG emission level disclosures. Prado-Lorenzo \& Garcia-Sanchez (2010) find no relation although Liao et al (2014) show female representation to positively influence carbon disclosures in the UK. We attempt to resolve these conflicting findings using a sample of Canadian firms from 2008 to 2014, by first identifying the critical mass of female directors required to effect disclosure and also by controlling for endogeneity from selfselection bias (Adams \& Ferreira, 2009). These enhancements are predicted to elucidate the gender diversity-CSR disclosure relation in a global climate of increased female representation on boards. 
Equal opportunity in the workplace is a basic human right. But is this opportunity afforded to females who wish to be part of the 'apex of the decision-making process' (Kassinis \& Vafeas, 2002) the corporate board? The 'old boys' network' attitude should not prevail when nominations are sought for board appointment yet, the percentage of female directors on Canadian boards suggests otherwise, compared to international standards. The methodical exclusion of a portion of society, because of gender and not talent, results in sub-optimal boards, (Carver, 2002; Cassell, 2000). The issue of female representation on boards for improvement in decision making due to their ethical behavior in the workplace remains unresolved. The Lehman Sisters hypothesis has been put forward, arguing that the banking crisis would not have occurred if there had been more women at the top (van Staveren, 2014), while others show no difference in ethical behavior between males and females (Hegarty and Sims, 1978; 1979)

The board of directors has two different roles, one of monitoring (control role) of managers and the second is to provide resources (service role). With regards to the former, the separation of ownership and control (Berle \& Means, 1932) with the resultant potential for conflict of interests means the board is responsible for monitoring managers on the behalf of shareholders. This first role has been analyzed through agency theory (Jensen \& Meckling 1976; Fama \& Jensen 1983). The latter role is to provide resources (service role) and this service role has been analyzed through the research streams of resource dependence theory (RDT) (Pfeffer 1972; Pfeffer \& Salanick 1978; Hillman et al 2000) and stakeholder theory (Johnson \& Greening 1999; Luoma \& Goodstein 1999; Hillman \& Keim 2001; Huse 2003). We utilize RDT in exploring the relationship between female representation on boards and the voluntary disclosure of climate change information. 
Females bring different characteristics to boards where they are perceived to have a more participative, democratic and communal leadership style (Eagly et al., 2003; Eagly \& Johnson, 1990; Rudman \& Glick, 2001). This may lead to improved board effectiveness as a result of the improved quality of board deliberations and better supervision of the firm's disclosures (Gul et al 2011).

Nielsen \& Huse (2010, page 138) suggest that "women may be particularly sensitive to - and may exercise influence on - decisions pertaining to certain organizational practices, such as corporate social responsibility and environmental politics." With regard to the latter, the demand for increased climate change disclosure is a global phenomenon ${ }^{1}$ driven by interested stakeholders seeking to assess a firm's environmental impact and the associated risks (Stanny \& Ely, 2008). Recent academic research suggests that information intermediaries in the capital markets incorporate environmental, social and governance data in their valuation models (Ioannou and Serafeim, 2010; Eccles et al., 2011). However these stakeholders; employees, customers, analysts and institutional shareholders find it difficult to assess the above given the lack of comparability and consistency on environmental reporting across firms.

The Carbon Disclosure Project (CDP), a not-for-profit organization that has the backing of 767 financial institutions controlling assets of $\$ 92$ trillion in 2014, seeks to remedy this deficiency by employing a standard questionnaire in requesting this information directly from firms. Since 2003, the CDP has requested annually the largest companies (top 200 companies in Canada) from

\footnotetext{
${ }^{1}$ In June 2012, The United Kingdom (UK) government announced that, starting from April 2013, all companies listed on the main market of the London Stock Exchange will be required to disclose their GHG emission levels in the annual reports. In February 2010, The United States (US) Securities and Exchange Commission (SEC) issued an interpretive guidance on climate change related risks to help US firms comply with their disclosure obligations.
} 
different countries across the globe to respond to the same set of questions and disclose their greenhouse gas (GHG) emissions, climate changes risks and opportunities and strategies to address them (Kolk et al., 2008). Recent studies provide evidence that voluntary disclosure of GHG emission levels to the CDP are value relevant for investors (Griffin et al. 2010; Matsumura et al., 2014). It is the board's responsibility to ensure that material environmental risks are well monitored and fully disclosed to investors and thus we relate female board participation (board gender diversity) to the firm's decision to voluntarily respond to the CDP annual questionnaire.

We examine the relationship between female representation on the board and the propensity to provide climate change disclosures for a sample of 541 firm year observations listed on the Toronto Stock Exchange (TSX) over the period 2008-2014. Board gender diversity is measured through the percentage of women directors on the board and the Blau (1977) index of heterogeneity. Female participation in the boardroom increases the likelihood of voluntary disclosure of climate change related risks in the CDP. We find also that female board participation needs to reach a critical mass of three before it starts influencing disclosures about climate change strategies. Our results are robust to potential endogeneity issues.

This paper makes several contributions to the extant literature on board diversity and environmental reporting. First, we assess the relationship between female representation on boards and the firm's decision to voluntarily disclose climate change information, the related risks and opportunities that has been requested specifically by a major stakeholder (i.e. institutional investors). Since institutional investors are actively seeking change on board diversity and climate 
change disclosure, we add to the existing CSR literature by exploring how board gender diversity may shape corporate response to institutional investors' demands for increased public reporting about climate change risks. This issue is important because greenhouse gas (GHG) emissions measurement and public disclosure to investors can be thought of as a first step towards addressing climate change issues and reducing the company's carbon footprint (Reid and Toffel, 2009).

Second, our paper contributes to the corporate governance literature by examining the link between firm level board diversity and sustainability disclosures in a setting where the disclosure of information is voluntary but not discretionary (Luo et al., 2012). Prior research examining the association between board diversity and sustainability disclosures relies on data from, stand-alone sustainability reports, annual reports and company websites, (Post et al., 2011; Seto-Pamies, 2013 and Fernandez-Feijoo et al., 2014). Thus managers enjoy total discretion over what to report on environmental issues, (Luo et al. 2012). Whilst firms voluntarily respond to the CDP annual survey, those that do must answer the same questions in a standard questionnaire. The lack of comparability between firms when using multiple sources of environmental data is negated because the CDP data is derived from the same questionnaire, (Luo et al. 2012).

Previous studies examine the relationship between female board participation and general sustainability (social and environmental) disclosures (Post et al 2011; Seto-Pamies, 2013 and Fernandez-Feijoo, 2014). However we focus on climate change disclosures because of the economic significance of global warming related risks and the devastating effects of GHG emissions on the environment (Luo et al. 2012). Two related studies (Prado-Lorenzo \& GarciaSanchez, 2010; Liao et al. 2014) examine the effect of gender diversity on GHG emission 
disclosures and provide mixed evidence. While Liao et al. (2014) report a positive effect of female presence on 2010 carbon disclosures in the United Kingdom (UK), Prado-Lorenzo \& GarciaSanchez (2010) did not find any effect of gender diversity in the boardroom on GHG disclosures for a sample of 283 Global companies which answered the CDP questionnaire in 2008. Our work differs from previous studies with regards to the extended sample from 2008 to 2013 in a climate of increasing female participation on boards, scope in terms of voluntary climate change disclosure and proportion of female directors on boards and the critical mass of female directors and methodology, where endogeneity is accounted for.

We focus on this issue in Canada, a country with minimal requirements regarding gender diversity in corporate boardrooms and GHG emission levels disclosure. Until 2014, Canadian companies were not required to disclose the proportion of women on boards and in senior management positions. Further, under the 'materiality' concept, managers enjoy a wide discretion on the disclosure on climate change related risks (Henderson, 2009). Unlike others such as PradoLorenzo \& Garcia-Sanchez (2010) and Liao et al. (2014), we empirically demonstrate the effects of a critical mass of women directors on voluntary climate change disclosures. Finally, the aforementioned previous studies did not address endogeneity issues that may result from selfselection bias related to the appointment of women directors to the board (Adams and Ferreira, 2009). Our paper addresses this important issue.

The paper is structured as follows. The next section summarizes prior literature and develops our research hypotheses. The third section describes our sample and method. The fourth section presents our results and a conclusion follows. 


\section{Related Literature and Research Hypotheses}

\section{Global Response to the demands to increase female board participation}

The demand to change the composition of corporate boards is global and is driven by the publication of corporate rankings on board diversity, media attention, calls from stakeholders, legal or regulatory changes and the development of good corporate governance practices. The global response has been that countries adopt either a coercive, enabling or laissez-faire approach (Labelle, Francoeur and Lakhal, 2014) ${ }^{2}$. France, Italy, Norway and Spain have introduced mandatory quotas for female representation on corporate boards, known as the "feminization" laws (de Beaufort and Summers, 2013).

Other countries such as Australia, United Kingdom and the United States have relied on a comply or explain approach to promote female board participation. The Financial Reporting Council amended the UK Corporate Governance Code which requires listed companies to establish a policy concerning boardroom diversity in its comply or explain regime. In the UK, "FTSE 100 boards should aim for a minimum of $25 \%$ female representation by 2015 and there is an expectation that many will achieve a higher figure" ${ }^{3}$. The European Commission has issued a proposal for a Directive of the European Parliament and of the Council regarding the disclosure of non-financial and diversity information by certain large companies and groups. The Commission has set a $40 \%$ target for female representation by 2020. Australia's ASX Corporate Governance Council made

\footnotetext{
${ }^{2}$ See Labelle et al. (2014) for a comprehensive summary of the different approaches used around the World to promote female representation on corporate boards.

${ }^{3}$ https://www.gov.uk/government/uploads/system/uploads/attachment_data/file/182602/bis-13-p135-women-onboards-2013.pdf
} 
amendments in 2010 to its ASX Corporate Governance Principles and Recommendations ${ }^{4}$. These amendments provide a reference point for listed companies with regard to two principles; structure the board to add value and promote ethical and responsible decision-making. The former recommends that the nominating committee considers diversity on the board, whilst the latter recommends that companies establish a policy concerning diversity, disclose the measureable objectives for achieving gender diversity and disclose in each annual report the proportion of women in the whole organization, in senior executive positions and on the board. In November 2010, SEC Commissioner Luis A. Aguilar quoted the Alliance for Board Diversity's report on diversity in Fortune 100 boards. It stated that the majority of board members, $71.5 \%$, were white men, and only $28.5 \%$ of the board seats were held by women and minorities ${ }^{5}$. Having sought the opinions of investors and corporations that controlled over $\$ 3$ trillion in assets, $90 \%$ of whom supported the disclosure of information on gender and race diversity on corporate board, the SEC approved rules to enhance such disclosure ${ }^{6}$. The SEC amended Regulation S-K to require companies to disclose "whether, and if so how, the nominating committee (or the board) considers diversity in identifying nominees for director"7. The SEC has not however defined diversity.

In contrast, until recently, Canada favoured a voluntary 'laissez-faire' approach. Canadian publicly listed firms were required neither to appoint a minimal number of women directors nor to disclose the proportion of women on boards and in senior management positions. Two main arguments have been developed in Canada with regard to female representation on boards, the rights argument

\footnotetext{
${ }^{4} \mathrm{http}: / /$ www.asx.com.au/documents/asx-compliance/cg_principles_recommendations_with_2010_amendments.pdf

5 http://www.sec.gov/news/speech/2010/spch110410laa.htm

${ }^{6} \mathrm{http://www.sec.gov/news/press/2009/2009-268.htm.}$

${ }^{7}$ US Securities and Exchange Commission, Release No. 33-9089, Proxy Disclosure Enhancements (December 16, 2009), http://www.sec.gov./rules/final/2009/33-9089.pdf
} 
and the functionalist argument. The rights argument is embodied in the Employment Equity Act (S.C. 1995, c. 44) in Canada, similar to legislation throughout the developed world, and seeks "to achieve equality in the workplace so that no person shall be denied employment opportunities or benefits for reasons unrelated to ability" . Moss (2004 p.2) suggests that females "rationally use level of diversity as a proxy for discrimination, since the latter is harder to observe'.

Despite this, numerous studies ${ }^{9}$ show that the percentage of female directors on Canadian boards is low by international standards. GMI Ratings' 2013 survey reveals that the percentage of female directors on Canadian boards is $13.1 \%$, an increase of less than one percentage point since 2009 . The average tenure of Canadian board members in 2013 was 8.6 years, similar to the US but substantially less than the UK. This finding, coupled with the slow rate of turnover of directorships (Canadian boards renewed at a rate of $7 \%$ in 2012), may explain the lack of female appointments to boards (Spizzirri, 2013). These figures are lower than in other developed countries. For instance, in the US, female participation on Fortune 500 boards was $12.4 \%$ in 2001, and after the introduction of SOX that percentage had increased to $16.1 \%$ by 2009 , (Dalton and Dalton, 2010).

To address this issue, the Ontario Securities Commission (OSC) introduced recently a 'Comply or Explain' regime to enhance women representation on boards of publicly listed companies. The new rules, which came into effect on December 31, 2014, are intended to increase transparency for investors and other stakeholders regarding the representation of women on boards of directors

\footnotetext{
${ }^{8}$ http://laws-lois.justice.gc.ca/eng/acts/E-5.401/page-1.html\#h-2

${ }^{9}$ Catalyst, 2012 Catalyst Census: Financial Post 500 Women Senior Officers and Top Earners (February 19, 2013), http://www.catalyst.org/knowledge/2012-catalyst-census-financial-post-500-women-senior-officers-and-top-earners . GMI Ratings, GMI Ratings' 2013 Women on Boards Survey (May 1, 2013), http://www3.gmiratings.com/home/2013/05/gmi-ratings2013-women-on-boards-survey. TD Economics, Get On Board Corporate Canada (March 7, 2013), http://www.td.com/document/PDF/economics/special/GetOnBoardCorporateCanada.pdf
} 
and in senior executive positions. Companies listed on the Toronto Stock Exchange are required to report on annual basis, in their proxy circular or annual information form, the number of women on boards and in senior management positions, and to disclose whether they have established internal targets for women participation. The new regulation also asks companies to provide disclosures about their policies to promote board renewal.

\section{Benefits of Female Representation on Boards}

Females are able to facilitate more informed decisions and bring different perspectives to boards compared to all male boards (Daily et al. 2000; Rose, 2007). As the proportion of female representation on boards increases, females have greater influence on the decision-making procedure (Elstad and Ladegard, 2010). This is the result of the moral influence on human systems (Nekhili, and Gatfoui, 2013). Concerns about the ethics of business executives exist especially when one considers the demise of Enron and Worldcom. A stream of literature examines the differences in ethical decision-making between male and female executives. Compared to their male counterparts, female marketing professionals demonstrate higher ethics research judgment (Akaah, 1989). This finding supports similar findings with regard to higher ethical standards in female college students compared to male, (Beltramini et al. (1984), and female researchers compared to male researchers, Ferrell and Skinner (1988). The findings of Bernardi, Bosco and Columb (2009) suggest that having a higher percentage of women on the board is associated with being listed as one of the 'World's Most Ethical Companies' if the firms is Fortune 500 company. Van Staveren (2014) analyzed the Lehman Sisters hypothesis (the claim that if there were more women at the top, the banking crisis would not have occurred) where the effect of gender differences on risk aversion, ethics and leadership were discussed. However the lack of significant 
differences in terms of ethical behavior between male and females has also been observed (Kidwell et al. 1987; Hegarty and Sims, 1978, 1979).

Since the actions of boards are confidential, the empirical literature is restricted to analyzing publicly available data that reflects the work of boards. In general, this literature examines the relationship between boards (gender diversity, independent vs. executive directors, governance rankings etc) and firm performance. With regard to gender diversity on boards and financial performance, the conclusion is that no consistent and robust relationship has been documented, (Rhode and Packel, 2010). A related stream of literature examines the relationship between board diversity and corporate social responsibility (CSR). CSR can be defined as the voluntary activities a corporation undertakes to operate in an economic, social and environmentally sustainable manner. Sharma and Henriques (2005) suggest that understanding a firm's internal drivers may reveal how corporations develop an understanding of sustainability and how they respond to this understanding. One such internal driver is board diversity and thus a number of studies explore the relationship between female representation on boards and CSR. Bear, Rahman and Post (2010) report that the number of females on the board has a positive relationship with the strength ratings ${ }^{10}$ for CSR and as the number of females on the board increases so too does the firm's CSR rating. Ciorcirlan and Pettersson (2012) suggest that different dimensions of workforce diversity influence a firm's commitment to fight climate change. In fact they find that the presence of women tends to be positively and significantly related to climate change commitment.

\footnotetext{
${ }^{10}$ The authors use the CSR ratings from the KLD database and focus on two social performance strength constructs, institutional strength ( a positive measure of community and diversity issues) and technical strength (a positive measure of product, government and employee issues).
} 
Socialization theory suggests that females have been socialized to be more nurturing, compassionate, focused on developing interpersonal skills and cooperative, (Skogen, 1999; Zelezeny et al. 2000).Thus the different characteristics that females bring to boards, a more participative, democratic and communal leadership style and their ability to facilitate more informed decisions (Eagley et al. 2003; Eagly and Johnson, 1990: Rudman and Glick, 2001), may result in improved board effectiveness as a result of the improved quality of board deliberations and better supervision of the firm's disclosures, compared to all male boards. It is suggested that females are more sensitive to corporate social responsibility and environmental issues, Nielsen and Huse (2010, page 138). For example, although Boulouta (2013) finds that board gender diversity influences corporate social responsibility, the effect is dependent on the social performance metric being tested. That is, boards that are more gender diverse affect the negative practices due to more emphatic caring by female directors. Empirical evidence on the effect of gender diversity on the dissemination of CSR information from different countries is mixed. For example, using a sample of multinational firms from 15 countries, Frias-Aceituno et al. (2013) find a positive association between board gender diversity and integrated reporting. In contrast, Prado-Lorenzo and GarciaSanchez (2010) find that the board of directors continues to concentrate on creating firm value rather than wider business concepts such as social responsibility. In particular, they report no significant influence of gender diversity on the dissemination of GHG information for S\&P500 firms.

To address the conflicting findings in the studies mentioned above, Ali, Ng and Kulik (2014) test competing linear and curvilinear models to test the diversity and performance relationship. From RDT, a positive linear relation is predicted; a negative linear relationship from social identity 
theory while an inverted U-shaped curvilinear is expected from an integration of both theories ${ }^{11}$. Ali et al (2014) emphasizes the importance of levels of diversity on performance where in some performance relations, the relation is non-linear. In addition, the theory chosen also affects the predicted relationship. As our outcome measure is not performance but rather the likelihood of voluntary disclosure of GHG emission levels and we focus on gender diversity, we use RDT to structure our hypothesis. According to Pfeffer and Salancik (1978), RDT asserts that an organization's external environment affects its performance where diverse boards are necessary to fulfil the board's many functions. For example, the integration of the differing skills and knowledge of male and female directors are crucial for decision making. Given our focus on the push to increase female representation on board, our prediction for Canadian firms is for a positive effect between gender diversity in the boardroom and the likelihood of voluntary disclosure of GHG emission levels and climate change related strategies.

\section{Hypothesis 1: There is a positive relation between female representation on the board of directors and the likelihood of voluntary climate change disclosure}

Previous studies (Konrad et al. 2008; Torchia et al. 2011; Joecks et al. 2013) argue also that women representation on boards needs to reach a 'critical mass' level before it can affect board members' decision-making process and firm performance. It is suggested that at least three women on boards constitutes a critical mass (Konrad et al. 2008). This stream of research relies on Kanter's (1977a, b) critical mass theory which predicts that 'until a certain threshold or critical mass of women in a

\footnotetext{
${ }^{11}$ The results show a positive linear relation between gender diversity and employee productivity, a negative linear relation between age diversity and ROA and also an inverted (U shaped) curvilinear relationship between age diversity and ROA.
} 
group is reached, the focus of the group members is not on the different abilities and skills that women bring into the group', Joecks et al. (2013, page 64). Therefore, board gender diversity has to be significant before it can be acceptable to all board members and enhances strategic decisionmaking (Ben-Amar et al. 2013). Consistent with the critical mass theory, Joecks et al (2013) report a U shaped relation between gender diversity and performance. At first, women directors have a negative effect on firm performance but when their presence on board reaches a level of $30 \%$, it improves firm performance. Torchia et al. (2011) find that a critical mass of women directors (i.e. three women directors and more) has a positive effect on firm innovation. Post et al. (2011) show that firms with three and more women directors have better CSR reporting practices. The notion of a need to reach a critical mass is aligned with social identity theory (Tajfel, 1978) where individuals identify with others into social groups based on demographics such as gender and age. When there is a critical mass of one type of demographical attribute, such as gender, female directors can interact more easily on the board to better its performance (Tuggle et al. 2011; Richard et al, 2013) .

In this paper, we rely on the critical mass theory to predict that firms with three or more female directors are more likely to provide climate change disclosures to the CDP.

\section{Hypothesis 2: There is positive relation between a critical mass of three or more women directors on the board and the likelihood of voluntary climate change disclosure}

\section{Research Method}

\section{Sample}

Our initial sample includes all firms with available corporate governance data in the Canadian Spencer Stuart Board Index (CSSBI) for the years 2008-2014. Spencer Stuart is one of the World's 
largest executive search firms. CSSBI assesses the corporate governance practices of the Top 100 publicly listed firms in Canada with annual revenues exceeding CAD1 billion. We then match the CSSBI 100 with the 200 firms covered in the CDP-Canada annual survey for the period 20082014. The first CDP questionnaire was sent to the top 200 publicly listed firms (by market capitalization) on the Toronto Stock Exchange (TSX) in 2006. These firms were asked to voluntarily complete a standard questionnaire on climate change related risks and opportunities, GHG emission accounting, carbon performance and governance. We also collect financial data from the commercial database Stock-Guide. Our initial sample comprises the CSSBI 100 for the years $2008-2014,700$ firms in total. Of these 700 firms, 134 firms were excluded due to missing CDP data and 25 due to missing financial data. Thus the final sample includes 541 firm year observations.

\section{Insert Table 1 here}

\section{Research Design and Variables}

Table 2 provides a description of our dependent, explanatory and control variables.

\section{Dependent Variable (DISC-DECISION)}

Our dependent variable, Disclosure Decision, is a dummy variable that equals one if the firm has responded to the CDP request for public disclosure of climate change strategies and greenhouse gas emissions and zero otherwise.

Independent Variable (Board Gender Diversity) 
We use three proxies of female representation on the board of directors. First we use the percentage of female directors, calculated as the number of women directors divided by the total number of directors. We also rely on the Blau (1977) index of heterogeneity as a proxy of board gender diversity. Miller and Triana (2009, page 766) argue that the Blau index is 'an ideal measure of diversity, because it meets the four criteria that have been laid out for a good measure of diversity: it has a zero point to represent complete homogeneity, larger numbers indicate greater diversity, the index does not assume negative values and the index is not unbounded'. Further, this index has been used in prior research (Campbell and Minguez-Vera, 2008; Miller and Triana, 2009; Jockes et al. 2013) which investigates the effects of board diversity on firm performance. Using Blau index, we measure board gender diversity as $H=1-\Sigma^{k}{ }_{i}=p_{i}{ }^{2}$, where $I=$ number of categories $(2$ for gender diversity) and $\mathrm{p}_{\mathrm{i}}=$ the proportion of group members (fraction of female and male directors) in each category. In the case of gender diversity, Blau index can take values from 0 when there is only one gender represented on the board to 0.5 when there are equal numbers of female and male directors in the boardroom. Finally, we also employ a binary variable that equals 1 if three or more women sit on the board to test the effect of a 'critical mass' of women directors on the propensity to provide climate change disclosures to the CDP.

\section{Control Variables}

Our paper controls for the effect of several variables which have been identified in the extant accounting literature to affect the firm's voluntary environmental disclosure. We control for other board attributes such as the percentage of independent directors, leadership structure and the existence and effectiveness of its standing committees. Prior research (Chen and Jaggi, 2000; Eng 
and Mak, 2003; Lim et al. 2007; Garcia-Meca and Sanchez-Ballesta, 2010) shows that board independence affects voluntary disclosure practices. Others including Gul and Leung (2004) and Cerbioni and Parbonetti (2007) report that the separation of the CEO and board chairperson positions has a positive effect on disclosure quality. Finally, there is mixed evidence on the impact of board committees' attributes on corporate disclosures (Karamanou and Vafeas, 2005; Cerbioni and Parbonetti, 2007; Laksmana, 2008). We therefore include the number of board's standing committees as a control in our multivariate analysis.

We also control for financial variables affecting voluntary disclosure practices. Previous research show that firm size is positively associated to environmental disclosure quality (Brammer and Pavelin, 2006; Clarkson et al. 2008; Stanny and Ely, 2008; Freedman and Jaggi, 2011; Luo et al. 2012). We control for firm size measured as the logarithm of total assets. Like prior research (Brammer and Pavelin, 2006; Stanny and Ely, 2008), we account for the effect of financial performance, measured by return on assets. Furthermore, we control for investment opportunities using the market value to book value of equity ratio. Firms with good growth opportunities (higher market-to-book ratios) should provide more environmental disclosures to reduce the information asymmetry between the firm and external investors.

Prior environmental disclosure research (Brammer and Pavelin, 2006; Stanny and Ely, 2008) also control for the effect of financial leverage on disclosure practices. Previous studies (Meek et al. 1995; Brammer and Pavelin, 2006; Stanny and Ely, 2008) suggest that a firm's industry is a key determinant of its voluntary disclosure strategy. Firms from carbon intensive industries are subject 
to higher climate change related risks and therefore we may expect these firms to provide more information about climate change related strategies than firms from low carbon industries. We follow the CDP (2008) methodology and define automobile \& components, chemicals, forest products, gas \& electrical utilities, oil \& gas, mining, pipelines, precious metals, steel \& transportation as high carbon impact industrial sectors.

\section{Insert Table 2 here}

We test the following model in our multivariate analysis:

DISC-DECISION $_{i t}=\alpha_{0}+\alpha_{1}$ Board Gender Diversity $_{\mathrm{it}-1}+\alpha_{2}$ Independence $_{\mathrm{it}-1}+\alpha_{3}$

CEONOTCOB $_{\mathrm{it}-1}+\alpha_{4}$ NBCommittees $_{\mathrm{it}-1}+\alpha_{5}$ SIZE $_{\mathrm{it}-1+} \alpha_{6}$ Profitability $_{\mathrm{it}-1}+\alpha_{7}$ Price-to-Book it- 1 $+\alpha_{8}$ Leverage $_{\mathrm{it}-1}+\alpha_{9}$ High-Carbon $_{\mathrm{it}}+\alpha_{\mathrm{i}}$ YearDummies $+\varepsilon_{\mathrm{i}}(1)$

Board gender diversity is measured by the proportion of women directors, Blau gender diversity index and binary variables for the number (one, two, three and more) of women directors.

Board gender diversity is likely to be influenced by board attributes (independence, leadership structure, number of standing committees) and other firm characteristics (firm size and profitability). Therefore, a regression model that includes gender diversity proxies and other firm characteristics on the right-hand side of the equation may suffer from endogeneity problems which may result in biased and inconsistent estimates (Greene, 2003). Previous studies (Campbell and Minguez-Vera, 2008; Adams and Ferreira, 2009; Srinidhi et al. 2011; Gul et al. 2011) discuss this 
endogeneity issue of self-selection bias related to the firm's decision to appoint females on boards and recommend the use of an instrumental variable approach to address it.

We rely therefore on a Probit model with continuous endogenous regressors (IV probit model in Stata) to address this potential problem. We use the number of directors (board size) and the existence of a mandatory retirement policy at the board of directors as exogenous instruments to predict the percentage of women directors. As suggested in Campbell and Minguez-Vera (2008), we expect board size to have a positive effect on the appointment of women directors. Furthermore, the existence of a mandatory retirement policy is likely to improve the rate of directorship turnover and the number of female appointments to boards. Adams and Ferreira (2009) suggest that better governed firms are more likely to appoint women directors. We therefore also include board independence, leadership structure (CEO is not the board chairperson) and the number of the board's standing committees as instruments to predict female board participation. Following Campbell and Minguez-Vera (2008), we also include firm size, profitability, leverage and priceto-book, industry and year dummies as instruments to explain board gender diversity.

\section{Results}

\section{Descriptive statistics}

Table 3 provides the distribution of the response rate to the CDP questionnaire by year. On average, $74.3 \%$ of the largest publicly listed firms in Canada accepted the CDP request and provided information about the potential effects of global warming. In contrast, $25.7 \%$ did not answer the 
CDP questionnaire or declined to participate. The average response rate has increased in 2014 and $2013(78.75 \%$ and $76.74 \%$ respectively) compared to $2012(62.9 \%)$.

\section{Insert Table 3 here}

Table 4 presents descriptive statistics on our sample firms' board gender diversity, corporate governance practices as well as other financial characteristics. The board of directors includes on average 12 directors among whom $80 \%$ are independent from management. Women hold on average $16 \%$ of board seats in our sample firms and the average Blau gender diversity score was 0.25. Twenty seven percent of our sample firms have appointed at least three women on their board of directors.

The position of board chairperson and chief executive officer (CEO) being held by the same person occurs only in $14 \%$ of cases in our sample. On average, boards of directors are structured around four standing committees which are audit, nomination/governance, compensation/human resources and environment, health and safety ${ }^{12}$. Table 4 shows also that on average, $30 \%$ of our sample firms have implemented a mandatory director retirement policy (age limits and/or term service limits). According to CSSBI (2010), the most common retirement age limit among the largest 100 Canadian companies in 2010 was 70 years while maximum term limits ranged from seven to 15 years of consecutive board service. Finally, $47 \%$ of our sample firms belong to a high carbon impact industry.

\section{Insert Table 4 here}

12 Other committees include pension/investment, Executive, Risk, Finance, Conduct Review, Social Responsibility/Public Policy and Strategy/Planning. 
Table 5 shows the correlation analysis. As expected, the decision to disclose is positively correlated with the percentage of women directors on boards and Blau gender diversity score. There are also positive and significant correlations between the percentage of independent directors on boards, separation of CEO and chairperson roles, number of board standing committees, firm size, profitability and the likelihood of voluntary climate change disclosures to the CDP. In contrast, firm leverage is negatively correlated. The largest correlation among explanatory variables involves price-t-book ratio and leverage (corr $=0.33$ ). The relatively low correlation coefficients among our explanatory variables suggest that multicollinearity may not be a serious threat in our multivariate analysis.

\section{Insert Table 5 here}

\section{Multivariate Analysis}

Table 6 presents the results of the Instrumental Variable (IV) Probit model (probit model with endogenous continuous regressors) regression of disclosure decision dummy on the board gender diversity and control variables.

Our first hypothesis posits that board gender diversity is positively related to the likelihood of voluntary climate change disclosure. The results in Table 6 show that the coefficients of the percentage of women directors (11.57) and Blau diversity index (8.81) are positive and significant at the $1 \%$ level. These results support the predictions of our first hypothesis. Reid and Toffel (2009, page 1174) suggest that the firm's public response to the CDP questionnaire 'requires an operational commitment to tracking greenhouse gas emissions, a normative commitment to the 
ethics of public disclosure, and an acknowledgment that climate change is an issue that requires some level of corporate attention'. Therefore, the firm's public disclosure of GHG emission levels may be seen as a first step towards addressing climate change issues and reducing of the company's carbon footprint. Our results suggest that the increasing presence of women on board enhances the firm's awareness about environmental issues and promotes the adoption of proactive strategies to respond to stakeholder demands for increased public reporting about climate change effects. Our findings are consistent with previous studies (Bear et al., 2010; Zhang et al., 2013) which report a positive association between gender diversity in corporate governance and the adoption of CSR practices at the firm level.

We also find that the number of the board's standing committees is positively related to voluntary disclosure of climate change strategies to the CDP. Previous research (Karamanou and Vafeas, 2005; Cerbioni and Parbonetti, 2007; Laksmana, 2008) suggests that board effectiveness will be contingent on the monitoring activities performed at the level of board committees. Our results suggest that board effectiveness is enhanced through activities performed at the committee level, which translate into more transparent disclosure about climate change effects and GHG emissions. Further, as the number of committees increase, it is more likely that the board will establish a standing committee on environmental and CSR issues. Such a committee will favor an increased awareness about the potential effects of climate change related risks on the firm's competitive advantage and may implement a proactive strategy to address them.

Among the remaining control variables, leverage and high carbon industry membership have a significant effect on voluntary climate change disclosures. Firms from high carbon impact industries are more likely to respond to institutional investors' requests for public reporting about climate change risks. We also find that leverage is negatively related to voluntary disclosure of 
climate change strategies. When we take into account endogeneity issues, it seems that firm size, profitability and growth opportunities have no significant impact on the firm's decision to respond to the CDP questionnaire. Finally, based on the results of the Wald test, we cannot reject the null hypothesis that there is no endogeneity in our model.

The results of the first stage regressions show that board gender diversity is explained by firmlevel governance attributes, firm size as well as industry patterns. Both models show that the separation of the CEO and board chairperson roles is positively related to the proportion of female representation on boards. Firm size has also a positive effect on the appointment of women directors. Finally, we can also see that women are less likely to serve on the boards of firms from high carbon impact industries such as energy and materials.

\section{Insert Table 6 here}

Our second hypothesis predicts that a board needs to reach a critical mass of women directors to have a positive effect on voluntary disclosures of climate change related risks. Following Torchia et al. (2011), we introduce three binary variables (onewoman, twowomen,threemorewomen) to test this hypothesis. The first binary variable takes the value of one if there is only one woman director and zero otherwise. The second takes the value of 1 when two women sit on boards. The third binary variable takes the value of one when there is at least three women directors on board and zero otherwise. By doing so, we can interpret the coefficient of each dummy variables relative to the baseline (all male boards). The results of the test of the critical mass hypothesis are presented in Table 7.

The coefficient of the onewoman binary variable is positive but not statistically significant. This results suggest that when there only one woman in a male dominated board, she may be perceived 
as a 'token' in the group and is less likely to affect the decision making process at the board level. The coefficients of the two other dummy variables (twowomen and threemorewomen) are positive and significant. This result is consistent with prior studies, (Konrad et al. 2008; Post et al. 2011) and supports the critical mass prediction. Unless boards have a critical mass of two female directors in our sample, the effect of women on the decision making process is limited. When this critical mass is reached, female presence has a positive impact on corporate response to stakeholders' demands to provide public disclosures about climate change related risks and strategies. Combined with the results of Table 6, our findings indicate that until there are two women directors on the board, gender diversity has no impact on climate change disclosure practices. Beyond this threshold, increased levels of female board participation have a positive impact on the likelihood to voluntarily provide disclosures to the $\mathrm{CDP}$ about GHG emission levels and climate change strategies.

Following Joecks et al. (2013) we also explored whether the relation between board gender diversity and voluntary climate change disclosure is $\mathrm{U}$ shaped. We ran regressions of climate change disclosure dummy on board gender diversity including a quadratic term (squared values of women percentage and Blau diversity index). We did not find any nonlinear relation between gender diversity proxies and climate change disclosures. These results are not tabulated for brevity.

\section{Insert Table 7 here}

\section{Conclusion}

This paper examines the potential impact of female representation on the board of directors on corporate response to stakeholder demands for increased public reporting about climate change 
related risks. We rely on the Carbon disclosure Project (CDP) as a sustainability initiative supported by an influential group of stakeholders (i.e. institutional investors). Greenhouse Gas (GHG) emissions measurement and its public disclosure to investors can be thought of as a first step towards addressing climate change issues and reducing a company's carbon footprint. Given the board of directors has a fiduciary duty to manage material risks to the firm, we examine the influence of board gender diversity on the firm's decision to respond voluntarily to the CDP annual questionnaire. We measure board gender diversity through the proportion of women directors and the Blau (1977) index of heterogeneity.

Based on sample of Canadian firm over the period 2008-2011, we find that female boardroom participation is positively related to the voluntary disclosure of climate change information, after board attributes and firm factors are taken into consideration. This result suggests that gender diversity enhances board effectiveness in stakeholder management and promotes the adoption of sustainability initiatives. Our results support recent research showing a positive effect of board gender diversity on the adoption of CSR practices (Bear et al. 2010; Zhang et al. 2013) and financial reporting quality (Gul et al. 2011; Srinidhi et al. 2011). We find also that board gender diversity needs to reach a critical mass of two women directors before it starts influencing board disclosures on GHG emission levels and climate change strategies. Our results are robust to potential endogeneity issues.

From a public policy perspective, our results are of interest to policymakers. Our findings are consistent with the different initiatives being undertaken in many countries around the world to 
promote gender diversity in corporate governance. Until 2014, there was no guideline in Canada regarding female representation on boards or in senior management positions. Further, Canadian listed companies were not required to disclose neither the proportion of women directors nor their gender diversity policies (OSC, 2013). Recently, the OSC introduced a 'Comply or Explain' approach with regard to women representation on boards of Canadian publicly listed firms. Our findings support the recent changes introduced by the OSC aiming to increase female participation on boards and in senior management positions. We show that women directors enhance corporate disclosure transparency with regards to climate change related risks.

However, these new requirements were also criticized by influential stakeholders as being insufficient to promote female presence on boards and ultimately board effectiveness. For instance, the Ontario Teachers' Pension Plan (OTPP), a global investor with $\$ 130$ billion of net assets, believes that the Canadian "comply or explain" approach to corporate governance and gender diversity in the boardroom does not work as planned. Instead, OTPP ${ }^{13}$ suggests a minimum of three women directors be appointed to boards of TSX listed firms. Our results on the critical mass theory support partially the OTPP position. Unless Canadian boardrooms include a critical mass of two women directors, gender diversity is unlikely to enhance board strategic decisions.

\footnotetext{
${ }^{13} \mathrm{http}$ //iveybusinessjournal.com/topics/governance/forcing-gender-diversity-on-canadian-boards
} 


\section{References}

Adams, R. B. and Ferreira, D. 2009. Women in the Boardroom and their Impact on Governance and Performance. Journal of Financial Economics, 94, 291-309.

Akaah, I. P. 1989. Differences in Research Ethics Judgments between Male and Female. Journal of Business Ethics, 8 (5), 375-381.

Ali, M., Ng, Y. L., and Kulik, C. T. 2014. Board age and gender diversity: A test of competing linear and curvilinear predictions. Journal of Business Ethics, 125 (3), 497-512.

Bear. S., Rahman. N. and Post. C. 2010. The Impact of Board Diversity and Gender Composition on Corporate Social Responsibility and Firm Reputation. Journal of Business Ethics, 97:207221.

Ben-Amar, W., Francoeur, C., Hafsi, T. and Labelle, R. 2013. What Makes Better Boards? A Closer Look at Diversity and Ownership, British Journal of Management, 24 (1), 85-101.

Berle, A. A. and Means, G.C. 1932. The Modern Corporation and Private Property. New York: Macmillan Publishing Co.

Bernardi, R.A., Bosco, S.M., and Columb, V.L. 2009. Does Female Representation on Boards of Directors Associate with the "Most Ethical Companies" List? Corporate Reputation Review, 12 (3), 270-280.

Beltramini, R., Peterson, R. A. and Kozmetsky G.: 1984, Concerns of College Students Regarding Business Ethics. Journal of Business Ethics, 3, 195-200.

Blau, P. M. 1977. Inequality and Heterogeneity. Glencoe, IL: Free Press.

Boulouta, I. 2013. Hidden Connections: The Link between Board Gender Diversity and Corporate Social Performance. Journal of Business Ethics, 113 (2), 185-197.

Brammer S, and Pavelin S. 2006. Voluntary Environmental Disclosure by Large UK Companies. Journal of Business Finance and Accounting, 33: 1168-1188.

Campbell, K. and Minguez-Vera, A. 2008, Gender Diversity in the Boardroom and Firm Financial 
Performance, Journal of Business Ethics, 83 (3), 435-451.

Carver, J. 2002, On Board Leadership (Jossey-Bass, SanFrancisco, CA).

Cassell, C. 2000, Managing Diversity in the New Millennium, Personnel Review, 29 (3), 268-274.

Chen, C. J. P., and Jaggi, B. 2000. Association between Independent Non-Executive Directors, Family Control and Financial Disclosures in Hong Kong. Journal of Accounting and Public Policy, 19(4-5), 285-310

Ciocirlan, C. and Pettersson, C. 2012. Does Workforce Diversity Matter in the Fight Against Climate Change? An Analysis of Fortune 500 Companies. Corporate Social Responsibility and Environmental Management, 19:47-62.

Clarkson, P.M., Li, Y., Richardson, G.D. and Vasvari, FP. 2008. Revisiting the Relation Between Environmental Performance and Environmental Disclosure: An Empirical Analysis. Accounting Organizations and Society, 33: 303-327.

Daily, C. M., Certo, S.T. and D. R. Dalton, D.R. 2000. The Future of Corporate Women: Progress toward the Executive Suite and the Boardroom? In R. J. Burke and M. C. Mattis (Eds.), Women on corporate boards of directors: International challenges and opportunities ( 1123). The Netherlands: Kluwer Academic Publishers.

Dalton, D.R. and Dalton, C.M. 2010. Women and Corporate Boards of Directors: The Promise of Increased, and Substantive, Participation in the Post Sarbanes-Oxley Era. Business Horizons, 53 (3) $257-268$

De Beaufort, V. and Summers, L. 2013. Women and Corporate Governance: Towards a New Model! Research Center ESSEC Working Paper 1312.

Eagly, A.H., and Johnson, B.T. 1990. Gender and Leadership Style: A Meta-Analysis. Psychological Bulletin, 108(2): 233-256.

Eagly, A.H., Johannsen-Schmidt, M.C., and Van Engen M. 2003. Transformational, Transactional and Laissez-Faire Leadership Styles: A Meta-Analysis Comparing Women and Men. Psychological Bulletin, 129: 569-591. 
Eccles, R.G., Krzus, M.P. and Serafeim, G. 2011. Market Interest in Nonfinancial Information. Journal of Applied Corporate Finance, 23: 4, 113-127.

Elstad, B., and Ladegard, G. 2010. Women on Corporate Boards: Key Influencers or Tokens? Journal of Management and Governance, 14(1), 1-21.

Eng, L. L., and Mak, Y. T. 2003. Corporate Governance and Voluntary Disclosure. Journal of Accounting and Public Policy, 22, 325-345.

Fama, E.F. and Jensen, M.C. 1983. Separation of Ownership and Control. Journal of Law and Economics, 26: 301-325.

Ferrell, O. C. and Skinner, J. S. 1988. Ethical Behavior and Bureaucratic Structure in Marketing Research Organizations, Journal of Marketing Research, 25, 103-109.

Fernandez-Feijoo, B., Romero, S., and Ruiz-Blanco, S. 2014. Women on Boards: Do They Affect Sustainability Reporting? Corporate Social Responsibility and Environmental Management, 21 (6), 351-364.

Freedman, M, and Jaggi, B. 2011. Global Warming Disclosures: Impact of Kyoto Protocol Across Countries. Journal of International Financial Management and Accounting, 22: 46-90.

Frias-Aceituno, J.V., Rodriguez-Ariza, L. and Garcia-Sanchez, I.M. 2013. The Role of the Board in the Dissemination of Integrated of Corporate Social Reporting, Corporate Social Responsibility and Environmental Management, 20 (4), 219-233.

Galbreath, J. 2011. Are There Gender-Related Influences on Corporate Sustainability? A Study of Women on Boards of Directors. Journal of Management and Organization, 17: 17-38.

García-Meca, E. and Sánchez-Ballesta, J.P. 2010. The Association of Board Independence and Ownership Concentration with Voluntary Disclosure: A Meta-Analysis, European Accounting Review, (3) 603-627.

Greene, W. H. 2003. Econometric Analysis, $5^{\text {th }}$ Edition, Prentice-Hall

Griffin, P.A., Lont, D.H. and Sun, Y. 2010. The Relevance to Investors of Greenhouse Gas 
Emission Disclosures. Working Paper, Social Science Research Network

Gul, F.A., Srinidhi, B. and Ng, A.C. 2011. Does Board Gender Diversity Improve Informativeness of Stock Prices? Journal of Accounting and Economics, 51, 314-338.

Gul, F.A. and Leung, S. 2004. Board Leadership, Outside Directors' Expertise and Voluntary Corporate Disclosures, Journal of Accounting and Public Policy, 23 (5), 351-379.

Hegarty , W. H. and Sims, H. P. 1978. Some Determinants of Unethical Decision Behavior. Journal of Applied Psychology, 63, 451-457.

Hegarty, W. H. and Sims, H.P. 1979. Organizational Philosophy, Policies, and Objectives Related to Unethical Decision Behavior: A Laboratory Experiment. Journal of Applied Psychology, 64(3), 331-338.

Henderson, G. 2009. The Materiality of Climate Change and the Role of Voluntary Disclosure. Comparative Research in Law and Political Science, 5: 1-19.

Hillman, A.J., Canella, A.A. and Paetzold, R.L., 2000. The Resource Dependence Role of Corporate Directors: Strategic Adaptation of Board Composition in Response to Environmental Change. Journal of Management Studies, 37(2), 235-256.

Hillman, A.J. and Keim, G.D. 2001. Shareholder Value, Stakeholder Management, and Social Issues: What's the Bottom Line? Strategic Management Journal, 22 (2), 125-139.

Huse, M. 2003. Renewing Management and Governance: New Paradigms of Governance? Journal of Management and Governance, 7, 211-221,

Ioannou, I, and Serafeim, G. 2010. The Impact of Corporate Social Responsibility on Investment Recommendations. Best paper proceedings of the academy of management, Annual Meeting.

Jensen, M.C., and Meckling, W.H. 1976. Theory of the Firm: Managerial Behaviour, Agency Costs And Ownership Structure. Journal of Financial Economics, 3, 305-360.

Joecks, J., Pull, K. and Vetter, K. 2013. Gender Diversity in the Boardroom and Firm Performance: What Exactly Constitutes a “Critical Mass?', Journal of Business Ethics, 118, 61-72. 
Johnson, R.A. and Greening, D.W. 1999. The Effects of Corporate Governance and Institutional Ownership Types on Corporate Social Performance, Academy of Management Journal, 42 (5), 564-576.

Kanter, R. M. 1977a. Men and Women of the Corporation (Basic Books, New York), 348 pages.

Kanter, R. M. 1977b. Some Effects of Proportion on Group Life: Skewed Sex Ratios and Responses to Token Women', American Journal of Sociology, 82 (5), 965-990.

Karamanou, I. and Vafeas, N. 2005. The Association between Corporate Boards, Audit Committees, and Management Earnings Forecasts: An Empirical Analysis, Journal of Accounting Research, 43 (3), 453-485.

Kassinis G, and Vafeas N. 2002. Corporate Boards and Outside Stakeholders as Determinants of Environmental Litigation. Strategic Management Journal, 23, 399-415.

Kidwell, J.M., Stevens, R.E. and Bethke, A.L. 1987. Differences in Ethical Perceptions between Male and Female Managers: Myth or Reality? Journal of Business Ethics, 6 (ㅁ) , 489-493.

Kolk, A. Levy , D. and Pinkse, J. 2008. Corporate Responses in an Emerging Climate Regime: The Institutionalization and Commensuration of Carbon Disclosure, European Accounting Review, 17 (4), 719-745.

Konrad, A. and Kramer, V.W. 2006. How Many Women Do Boards Need? Harvard Business Review, 84 (12), 22.

Konrad, A. M., Kramer, V., and Erkut, S. 2008. Critical Mass: The Impact of Three or More Women on Corporate Boards. Organizational Dynamics, 37(2), 145-164.

Labelle, R., Francoeur, C., and Lakhal, F. 2014. To Regulate or Not to Regulate? Early Evidence on the Means Used around the World to Promote Gender Diversity in the Boardroom, Forthcoming in Gender, Work \& Organization.

Laksmana, I. 2008. Corporate Board Governance and Voluntary Disclosure of Executive Compensation Practices, Contemporary Accounting Research, 25 (4), 1147-1182,

Liao, L., Luo, L. and Tang, Q. 2014. Gender Diversity, Board Independence, Environmental 
Committee and Greenhouse Gas Disclosure, Forthcoming in British Accounting Review.

Lim, S., Matolcsy, Z. and Chow, D. 2007. The Association between Board Composition and Different Types of Voluntary Disclosure, European Accounting Review, 16, (3) 555-587.

Luo, L., Lan, YC, and Tang, Q. 2012. Corporate Incentives to Disclose Carbon Information: Evidence from the CDP Global 500 Report. Journal of International Financial Management and Accounting, 23, 93-120.

Luoma, P. and Goodstein, J. 1999. Stakeholders and Corporate Boards: Institutional Influences on Board Composition and Structure, Academy of Management Journal, 42 (5), 553-563.

Matsumura, E.M., Prakash, R. and Vera-Munoz, S.C. 2014. Firm-Value Effects of Carbon Emissions and Carbon Disclosures. The Accounting Review, 89 (2): 695-724.

Meek, G.K., Roberts, C.,B.. and Gray, S.J. 1995. Factors Influencing Voluntary Annual Reports Disclosures By US, UK And European Multinational Corporations, Journal of International Business Studies, 3, 555-572.

Miller, T. and Triana, M. 2009. Demographic Diversity in the Boardroom: Mediators of the Board Diversity-Firm Performance Relationship, Journal of Management Studies, 46 (5), 755-786.

Moss, S. 2004. Women choosing diverse workplaces: A Rational Preference with Disturbing Implications for both Occupational Segregation and Economic Analysis of Law, Harvard Womens' Law Journal, 27, 1-88.

Nekhili, M. and Gatfoui, H. 2013. Are Demographic Attributes and Firm Characteristics Drivers of Gender Diversity? Investigating Women's Positions on French Boards of Directors. Journal of Business Ethics, 118, 227-249.

Nielsen, S. and Huse, M. 2010. The Contribution of Women on Boards of Directors: Going Beyond the Surface. Corporate Governance: An International Review, 18(2), 136-148.

Ontario Securities Commission. 2009. Corporate Sustainability Reporting Initiative. http://www.osc.gov.on.ca/documents/en/Securities-Category5/rule_20091218_51$\underline{717 \text { mof-rpt.pdf }}$ 
Ontario Securities Commission. 2013. OSC Staff Consultation Paper 58-401 (Disclosure Requirement Regarding Women on Boards and in Senior Management Positions).

Pfeffer, J. 1972a. Size and Composition of Corporate Boards of Directors: The Organization and its Environment, Administrative Science Quarterly, 17, 218-228.

Pfeffer, J. and Salancik, G. 1978. The External Control of Organizations: A Resource Dependence Perspective, Harper and Row, New York,

Post, C., Rahman, N, and Rubow, E. 2011. Green Governance: 'Boards of Directors' Composition and Environmental Corporate Social Responsibility, Business and Society, 50(1), 189-223.

Prado-Lorenzo, J. M. and Garcia-Sanchez, I. M. 2010. The Role of the Board of Directors in Disseminating Relevant Information on Greenhouse Gases, Journal of Business Ethics, 97(3), 391-424.

Reid, E.M. and Toffel, M.W. 2009. Responding to Public and Private Politics: Corporate Disclosure of Climate Change Strategies, Strategic Management Journal, 30 (11), 11571178.

Rhode, D. and Packel, A. K. 2010. Diversity Corporate Boards: How Much Difference Does Difference Make? Rock Center for Corporate Governance at Stanford University Working Paper, (89).

Richard, O. C., Kirby, S. L., \& Chadwick, K. 2013. The Impact of Racial and Gender Diversity in Management on Financial Performance: How Participative Strategy Making Features Can Unleash a Diversity Advantage. The International Journal of Human Resource Management, 24(13), 2571-2582.

Rose, C. 2007. Does Female Board Representation Influence Firm Performance? The Danish Evidence, Corporate Governance. 15 (2), 404-413.

Rudman, L.A. and Glick, P. 2001. Prescriptive Gender Stereotypes and Backlash Toward Agentic Women, Journal of Social Issues, 57 (4), 743-762.

Setó-Pamies, D. 2013. The Relationship between Women Directors and Corporate Social Responsibility. Corporate Social Responsibility and Environmental Management, (wileyonlinelibrary.com) DOI: 10.1002/csr.134 
Sharma, S, and Henriques, I. 2005. Stakeholder Influences on Sustainability Practices in the Canadian Forest Products Industry. Strategic Management Journal, 26, 159-180.

Skogen, K. 1999. Another Look at Culture and Nature: How Culture Patterns Influence Environmental Orientation Among Norwegian Youth, Acta Sociologica, 42, 223-239.

Spizzirri, A. 2013. S\&P/TSX Composite Index Director Tenure. http://www.rotman.utoronto.ca

Srinidhi, B., Gul, F.A. and Tsui, J. 2011. Female Directors and Earnings Quality, Contemporary Accounting Research, 28 (5), 1610-1644.

Stanny, E. and Ely, K. 2008. Corporate Environmental Disclosures about the Effects of Climate Change, Corporate Social Responsibility and Environmental Management, 15, 338-348.

Tajfel, H. E. 1978. Differentiation between social groups: Studies in the social psychology of intergroup relations. Academic Press.

Torchia, M., Calabrò, A. and Huse, M. 2011. Women Directors on Corporate Boards: From Tokenism to Critical Mass, Journal of Business Ethics, 102 (12), 299-317.

Tuggle, C. S., Sirmon, D. G., \& Bierman, L. (2011, February). From Seats at the Table to Voices in the Discussion: Exploring the Effects of Proportional Representation and Prestige on Minority Directors' Participation in Board Meeting Discussions. In Conference on Corporate Governance.

Van Staveren, I. 2014 The Lehman Sisters Hypothesis, Cambridge Journal of Economics, 2014, $1-20$.

Zelezny. L, Chua, P-P, and Aldrich, C. 2000. Elaborating on Gender Differences in Environmentalism, Journal of Social Issues, 56, 443-457.

Zhang, J.Q, Zhu, H and Ding, H.B. 2013. Board Composition and Corporate Social Responsibility: An Empirical Investigation in the Post Sarbanes-Oxley Era, Journal of Business Ethics, 114, 381-392. 
Table 1

Sample Composition

Final Sample by Year

\begin{tabular}{|l|c|c|c|c|c|c|c|c|}
\hline & 2008 & 2009 & 2010 & 2011 & 2012 & 2013 & 2014 & Total \\
\hline CSSBI & 100 & 100 & 100 & 100 & 100 & 100 & 100 & 700 \\
\hline No CDP data & 20 & 22 & 27 & 14 & 17 & 14 & 20 & 134 \\
\hline No Financial Data & 8 & 4 & 4 & 7 & 2 & & & 25 \\
\hline Final Sample & 72 & 74 & 69 & 79 & 81 & 86 & 80 & 541 \\
\hline
\end{tabular}

Table 2

Variable Description

\begin{tabular}{|c|c|c|}
\hline Variable & Description & Source \\
\hline \multicolumn{3}{|c|}{ Dependent Variable } \\
\hline DISC-DECISION & $\begin{array}{l}\text { Dummy variable that equals one if the firm } \\
\text { answered the CDP questionnaire }(\mathrm{AQ}=1) \\
\text { and zero otherwise. }\end{array}$ & CDP Reports \\
\hline \multicolumn{3}{|c|}{ Board Gender Diversity Variables } \\
\hline NB-WOMEN & $\begin{array}{l}\text { Number of women seating on the board of } \\
\text { directors }\end{array}$ & $\begin{array}{l}\text { Spencer Stuart } \\
\text { Canadian Board } \\
\text { index }\end{array}$ \\
\hline PERCENT-WOMEN & $\begin{array}{l}\text { Percentage of women on the board of } \\
\text { directors }\end{array}$ & $\begin{array}{l}\text { Spencer Stuart } \\
\text { Canadian Board } \\
\text { index }\end{array}$ \\
\hline BLAU-INDEX & $\begin{array}{l}\text { Blau (1977) index of heterogeneity. } \mathrm{H}=1- \\
\Sigma^{\mathrm{k}} \mathrm{i}_{\mathrm{I}} \mathrm{p}_{\mathrm{i}}{ }^{2} \text {, where } \mathrm{I}=\text { number of categories }(2 \\
\text { for gender diversity) and } \mathrm{p}_{\mathrm{i}}=\text { the } \\
\text { proportion of group members (fraction of } \\
\text { female and male directors) in each } \\
\text { category. }\end{array}$ & $\begin{array}{l}\text { Spencer Stuart } \\
\text { Canadian Board } \\
\text { index }\end{array}$ \\
\hline 3WOMEN & $\begin{array}{l}\text { Dummy variable that equals } 1 \text { if there at } \\
\text { least } 3 \text { women seating on the board of } \\
\text { directors and zero otherwise }\end{array}$ & $\begin{array}{l}\text { Spencer Stuart } \\
\text { Canadian Board } \\
\text { index }\end{array}$ \\
\hline \multicolumn{3}{|c|}{ Control Variables } \\
\hline
\end{tabular}




\begin{tabular}{|c|c|c|}
\hline INDEPENDENCE & $\begin{array}{l}\text { Percentage of independent directors on the } \\
\text { board }\end{array}$ & $\begin{array}{l}\text { Spencer Stuart } \\
\text { Canadian Board } \\
\text { index }\end{array}$ \\
\hline CEONOTCOB & $\begin{array}{l}\text { Dummy variable that equals } 1 \text { if the CEO } \\
\text { is not the board chairperson and zero } \\
\text { otherwise }\end{array}$ & $\begin{array}{l}\text { Spencer Stuart } \\
\text { Canadian Board } \\
\text { index }\end{array}$ \\
\hline NBCOMMITTEES & Number of board standing committees & $\begin{array}{l}\text { Spencer Stuart } \\
\text { Canadian Board } \\
\text { index }\end{array}$ \\
\hline SIZE & Firm size (Logarithm of total assets) & Stock-Guide \\
\hline PROFITABILITY & Return on assets & Stock-Guide \\
\hline PRICE-TO-BOOK & Price to book value of equity & Stock-Guide \\
\hline LEVERAGE & Debt-to-equity ratio & Stock-Guide \\
\hline HIGH-CARBON & $\begin{array}{l}\text { Dummy variable that equals } 1 \text { if the firm } \\
\text { belongs to a high carbon impact industrial } \\
\text { sector. High-carbon impact industries } \\
\text { include Automobiles \& components, } \\
\text { Chemicals, Forest products, Gas \& } \\
\text { Electrical Utilities, Oil \& gas, Mining, } \\
\text { Pipelines, Precious Metals, Steel and } \\
\text { Transportation. }\end{array}$ & CDP Reports \\
\hline \multicolumn{3}{|c|}{ Instruments } \\
\hline BOARDSIZE & Total number of directors & $\begin{array}{l}\text { Spencer Stuart } \\
\text { Canadian Board } \\
\text { index }\end{array}$ \\
\hline MANDATORYRET & $\begin{array}{l}\text { Dummy variable that equals } 1 \text { if the board } \\
\text { has a mandatory retirement policy for } \\
\text { directors and zero otherwise. }\end{array}$ & $\begin{array}{l}\text { Spencer Stuart } \\
\text { Board index }\end{array}$ \\
\hline
\end{tabular}


Table 3

Response Rate by Year

\begin{tabular}{|l|l|l|l|}
\hline & Total & $\begin{array}{l}\text { Number (\%) of firms that } \\
\text { answered the CDP questionnaire }\end{array}$ & $\begin{array}{l}\text { Number (\%) of firms } \\
\text { that did not answer the } \\
\text { CDP questionnaire }\end{array}$ \\
\hline 2008 & 72 & $54(75 \%)$ & $18(25 \%)$ \\
\hline 2009 & 74 & $55(74.32 \%)$ & $19(25.68 \%)$ \\
\hline 2010 & 69 & $51(73.91 \%)$ & $18(26.09 \%)$ \\
\hline 2011 & 79 & $62(78.48 \%)$ & $17(21.52 \%)$ \\
\hline 2012 & 81 & $51(62.96 \%)$ & $30(37.04 \%)$ \\
\hline 2013 & 86 & $66(76.74 \%)$ & $20(23.26 \%)$ \\
\hline & 80 & $63(78.75 \%)$ & $17(21.25 \%)$ \\
\hline & 541 & $402(74.30 \%)$ & $141(25.70 \%)$ \\
\hline
\end{tabular}


Table 4

Descriptive statistics

This table presents descriptive statistics. See Table 1 for variable definition. The sample includes 294 firm-year observations for publicly listed companies with available corporate governance data in the CSSBI over the period 2008-2011.

\begin{tabular}{|c|c|c|c|c|c|c|}
\hline Variable & $\mathbf{N}$ & Mean & Median & Std-dev & Minimum & Maximum \\
\hline \multicolumn{7}{|c|}{ DEPENDENT VARIABLE } \\
\hline DISC-DECISION & 541 & 0.74 & 1 & 0.43 & 0 & 1 \\
\hline \multicolumn{7}{|c|}{ BOARD GENDER DIVERSITY VARIABLES } \\
\hline NB-WOMEN & 541 & 1.95 & 2.00 & 1.20 & 0 & 6 \\
\hline PERCENT-WOMEN & 541 & 0.16 & 0.15 & 0.09 & 0 & 0.57 \\
\hline BLAU-INDEX & 541 & 0.25 & 0.26 & 0.11 & 0 & 0.49 \\
\hline OneWoman & 541 & 0.29 & & 0.46 & 0 & 1 \\
\hline TwoWomen & 541 & 0.34 & & 0.47 & 0 & 1 \\
\hline ThreeWomenMore & 541 & 0.27 & & 0.44 & 0 & 1 \\
\hline \multicolumn{7}{|c|}{ CORPORATE GOVERNANCE VARIABLES } \\
\hline BOARDSIZE & 541 & 11.86 & 12 & 2.76 & 6 & 21 \\
\hline INDEPENDENCE & 541 & 0.80 & 0.83 & 0.12 & 0.28 & 1 \\
\hline CEONOCOB & 541 & 0.86 & & 0.34 & 0 & 1 \\
\hline NBCOMMITTEES & 541 & 4.04 & 4 & 1.05 & 2 & 7 \\
\hline MANDATORYRET & 541 & 0.30 & & 0.46 & 0 & 1 \\
\hline \multicolumn{7}{|c|}{ OTHER CONTROL VARIABLES } \\
\hline SIZE & 541 & 13.25 & 14.62 & 3.73 & 6.82 & 20.40 \\
\hline PROFITABILITY (\%) & 541 & 3.45 & 2.99 & 8.27 & -117.5 & 45.62 \\
\hline PRICETOBOOK & 541 & 2.19 & 2.57 & 1.66 & 0 & 23.97 \\
\hline LEVERAGE & 541 & 0.82 & 0.50 & 0.89 & 0 & 7.07 \\
\hline HIGHCARBON & 541 & 0.47 & & 0.50 & 0 & 1 \\
\hline
\end{tabular}




\section{Table 5}

\section{Correlation Matrix}

This table presents pairwise correlations among dependent, independent and control variables. See Table 1 for variable definition. The sample includes 541 firm-year observations for publicly listed companies with available corporate governance data in the CSSBI over the period 20082014. * denotes significance at the $5 \%$ level

\begin{tabular}{|c|c|c|c|c|c|c|c|c|c|c|c|}
\hline & 1 & 2 & 3 & 4 & 5 & 6 & 7 & 8 & 9 & 10 & 11 \\
\hline 1-DISC-DECISION & 1 & & & & & & & & & & \\
\hline 2-PERCENTWOMEN & $0.23 *$ & 1 & & & & & & & & & \\
\hline 3- BLAU INDEX & $0.25^{*}$ & $0.97 *$ & 1 & & & & & & & & \\
\hline 4. INDEPENDENCE & $0.25^{*}$ & $0.15^{*}$ & $0.17 *$ & 1 & & & & & & & \\
\hline 5. CEONOTCOB & & $0.25 *$ & $0.28 *$ & $0.16 *$ & 1 & & & & & & \\
\hline 6. NBCOMMITTEES & $0.21 *$ & -0.06 & -0.03 & $0.13 *$ & $0.12 *$ & 1 & & & & & \\
\hline 7. SIZE & $0.10 *$ & -0.01 & 0.01 & 0.01 & 0.04 & $0.13 *$ & 1 & & & & \\
\hline 8. PROFITABILITY & 0.03 & 0.02 & 0.01 & -0.05 & -0.01 & -0.05 & $-0.11 *$ & 1 & & & \\
\hline 9. PRICETOBOOK & -0.01 & $0.13 *$ & $0.12 *$ & -0.03 & 0.01 & -0.01 & -0.07 & $0.14 *$ & 1 & & \\
\hline 10. LEVERAGE & $-0.18 *$ & $0.10 *$ & $0.11 *$ & -0.01 & -0.05 & $-0.10^{*}$ & 0.03 & $-0.12 *$ & $0.33 *$ & 1 & \\
\hline 11. HIGHCARBON & & $-0.18^{*}$ & $-0.18^{*}$ & 0.05 & & $0.31 *$ & -0.06 & -0.01 & -0.03 & $-0.06-$ & 1 \\
\hline
\end{tabular}




\section{Table 6}

\section{Board Gender Diversity and Carbon Disclosure Decision}

This table presents the results of an Instrumental Variable Probit regression of Carbon Disclosure Decision on board gender diversity and control Variables. See Table 1 for variable definition. The sample includes 294 firm-year observations for publicly listed companies with available corporate governance data in the CSSBI over the period 2008-2014. Heteroskedasticity adjusted (White, 1980) standard errors are used to compute z-statistics. $*$, ** and $* * *$ denote significance at the $10 \%, 5 \%$ and $1 \%$ levels respectively

\begin{tabular}{|c|c|c|c|c|}
\hline p & \multicolumn{2}{|c|}{ (n) } & \multirow{2}{*}{ First Stage } & \multirow{2}{*}{ Second Stage } \\
\hline & First Stage & Second Stage & & \\
\hline & Percent Women & Disclosure Decision & Blau Index & Disclosure Decision \\
\hline & $\begin{array}{l}\text { Coefficient } \\
\text { (z-statistic) }\end{array}$ & $\begin{array}{l}\text { Coefficient } \\
\text { (z-statistic) }\end{array}$ & $\begin{array}{l}\text { Coefficient } \\
\text { (z-statistic) }\end{array}$ & $\begin{array}{l}\text { Coefficient } \\
\text { (z-statistic) }\end{array}$ \\
\hline PERCENTWOMEN & & $\begin{array}{c}11.57 * * * \\
(4.64)\end{array}$ & & \\
\hline BLAU INDEX & & & & $\begin{array}{c}8.81 * * * \\
(4.95)\end{array}$ \\
\hline \multicolumn{5}{|l|}{ CONTROL VARIABLES } \\
\hline INDEPENDENCE & $\begin{array}{c}0.05 \\
(0.76)\end{array}$ & $\begin{array}{c}0.53 \\
(0.34)\end{array}$ & $\begin{array}{c}0.07 \\
(0.90)\end{array}$ & $\begin{array}{c}0.64 \\
(0.45)\end{array}$ \\
\hline CEONOTCOB & $\begin{array}{c}0.06 * * * \\
(3.15)\end{array}$ & $\begin{array}{l}-0.26 \\
(-0.45)\end{array}$ & $\begin{array}{c}0.09 * * * \\
(3.00)\end{array}$ & $\begin{array}{c}-0.29 \\
(-0.53)\end{array}$ \\
\hline NBCOMMITTEES & $\begin{array}{c}-0.01 \\
(-1.35)\end{array}$ & $\begin{array}{c}0.16^{* *} \\
(2.18)\end{array}$ & $\begin{array}{c}-0.01 \\
(-1.06)\end{array}$ & $\begin{array}{l}0.15 * \\
(1.88)\end{array}$ \\
\hline FIRM SIZE & $\begin{array}{l}0.01 * \\
(1.89)\end{array}$ & $\begin{array}{c}0.01 \\
(0.05)\end{array}$ & $\begin{array}{c}0.012 * \\
(1.86)\end{array}$ & $\begin{array}{c}0.01 \\
(0.09)\end{array}$ \\
\hline PROFITABILITY & $\begin{array}{c}0.00 \\
(0.75) \\
\end{array}$ & $\begin{array}{c}0.00 \\
(0.08) \\
\end{array}$ & $\begin{array}{c}0.00 \\
(0.49) \\
\end{array}$ & $\begin{array}{c}0.00 \\
(0.32) \\
\end{array}$ \\
\hline PRICETOBOOK & $\begin{array}{c}0.01 \\
(1.42) \\
\end{array}$ & $\begin{array}{c}-0.03 \\
(-0.62) \\
\end{array}$ & $\begin{array}{c}0.01 \\
(1.36) \\
\end{array}$ & $\begin{array}{c}-0.02 \\
(-0.51)\end{array}$ \\
\hline LEVERAGE & $\begin{array}{c}0.00 \\
(0.39)\end{array}$ & $\begin{array}{l}-0.25 \\
(-1.54)\end{array}$ & $\begin{array}{c}0.01 \\
(0.55)\end{array}$ & $\begin{array}{c}-0.28 * * \\
(-2.08)\end{array}$ \\
\hline HIGHCARBON & $\begin{array}{l}-0.02 * \\
(-1.69)\end{array}$ & $\begin{array}{l}0.34 * \\
(1.85)\end{array}$ & $\begin{array}{c}-0.034 * \\
(-1.67)\end{array}$ & $\begin{array}{l}0.34 * \\
(1.80)\end{array}$ \\
\hline BOARD SIZE & $\begin{array}{c}0.00 \\
(0.36) \\
\end{array}$ & & $\begin{array}{l}0.001 \\
(0.57) \\
\end{array}$ & \\
\hline MANDATORYRET & $\begin{array}{c}0.02 \\
(1.23)\end{array}$ & & $\begin{array}{c}0.03 \\
(1.46)\end{array}$ & \\
\hline INTERCEPT & $\begin{array}{c}-0.10 \\
(-1.31)\end{array}$ & & $\begin{array}{c}-0.12 \\
(-1.35)\end{array}$ & \\
\hline Year Dummies & Yes & Yes & Yes & Yes \\
\hline Nb. observations & 541 & 541 & 541 & 541 \\
\hline Wald Chi 2 & & $269.70 * * *$ & & $257.62 * * *$ \\
\hline Wald Test of Exogeneity: & & $\begin{array}{l}\text { Chi2(1): } 1.64 ; \\
\text { Prob }>\text { chi } 2=0.20\end{array}$ & & $\begin{array}{c}\text { Chi2(1):2.15; } \\
\text { Prob }>\text { chi2 }=0.143\end{array}$ \\
\hline
\end{tabular}




\section{Table 7}

Critical Mass of Women Directors and Carbon Disclosure Decision

This table presents the results of a Probit regression of Carbon Disclosure Decision on three women director dummy and control Variables. See Table 1 for variable definition. The sample includes 294 firmyear observations for publicly listed companies with available corporate governance data in the CSSBI over the period 2008-2011. Heteroskedasticity adjusted (White, 1980) standard errors are used to compute Z-statistics. $*, * *$ and $* * *$ denote significance at the $10 \%, 5 \%$ and $1 \%$ levels respectively

\begin{tabular}{|c|c|c|}
\hline & \multicolumn{2}{|c|}{$\begin{array}{c}\text { Model 1 } \\
\text { DISC-DECISION }\end{array}$} \\
\hline & Coefficient & Z-stat \\
\hline ONEWoman & 0.19 & 0.48 \\
\hline TWOWomen & 0.69 & $1.69 *$ \\
\hline 3WOMENMORE & 1.14 & $2.49 * *$ \\
\hline INDEPENDENCE & 2.03 & $2.23 * *$ \\
\hline CEONOTCOB & 0.38 & 1.04 \\
\hline NBCOMMITTEES & 0.15 & 1.17 \\
\hline FIRM SIZE & 0.20 & $2.20 * *$ \\
\hline PROFITABILITY & 0.015 & 1.48 \\
\hline PRICETOBOOK & -0.02 & -0.27 \\
\hline LEVERAGE & -0.32 & $-2.12 * *$ \\
\hline HIGHCARBON & 0.46 & $1.68 *$ \\
\hline INTERCEPT & -5.45 & $-3.49 * * *$ \\
\hline YEAR DUMMIES & Yes & \\
\hline Nb. observations & 541 & \\
\hline Wald Chi $^{2}$ & $55.11 * * *$ & \\
\hline Pseudo-R ${ }^{2}$ & $24.80 \%$ & \\
\hline
\end{tabular}

